\title{
Recombinant Env proteins that bind the quaternary-specific, V1/V2-directed PGT antibodies
}

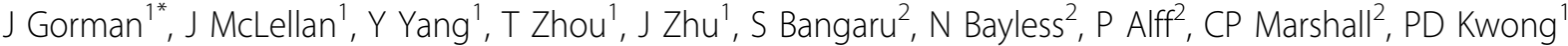 \\ From AIDS Vaccine 2012 \\ Boston, MA, USA. 9-12 September 2012
}

\section{Background}

Antibodies PGT141-145 are broadly neutralizing and recognize a glycan-dependent epitope in the V1/V2 loop, similar to antibodies PG9 and PG16. Collectively, this class of antibodies binds preferentially to the functional viral spike. Although PG9, and to a lesser extent, PG16, bind monomeric gp120s and V1/V2 scaffolds, to date no recombinant env-derived proteins have been identified that bind to antibodies PGT141-145.

\section{Methods}

As a first step toward obtaining structural information of the epitope recognized by PGT141-145, we have created and characterized novel gp140s and epitope scaffolds designed to present the V1/V2 conformation recognized by PGT141-145. To date, over 70 recombinant proteins have been expressed and tested for antibody binding.

\section{Results}

We have identified one V1/V2-scaffold protein that binds to PGT142. The binding is dependent on the HIV-1 strain used in the scaffold. We have also produced trimeric, cleaved gp140 constructs and evaluated them for binding to PGT141-145.

\section{Conclusion}

Proteins that accurately mimic V1/V2 conformations of the functional viral spike are crucial to obtaining structures of the PGT antibodies in complex with their epitopes, and may be ideal immunogens for eliciting broadly neutralizing, V1/V2-directed antibodies in a vaccine setting.
Author details

${ }^{1}$ National Institutes of Health, Bethesda, MD, USA. ${ }^{2}$ Avatar Biotechnologies, Brooklyn, NY, USA.

Published: 13 September 2012

doi:10.1186/1742-4690-9-S2-P84

Cite this article as: Gorman et al:: Recombinant Env proteins that bind the quaternary-specific, V1/V2-directed PGT antibodies. Retrovirology 20129 (Suppl 2):P84.
Submit your next manuscript to BioMed Central and take full advantage of:

- Convenient online submission

- Thorough peer review

- No space constraints or color figure charges

- Immediate publication on acceptance

- Inclusion in PubMed, CAS, Scopus and Google Scholar

- Research which is freely available for redistribution
C Biomed Central

${ }^{1}$ National Institutes of Health, Bethesda, MD, USA

Full list of author information is available at the end of the article

○ 2012 Gorman et al; licensee BioMed Central Ltd. This is an Open Access article distributed under the terms of the Creative Commons 